\title{
Long-chain saturated fatty acid species are not toxic to human pancreatic $\beta$-cells and may offer protection against pro-inflammatory cytokine induced $\beta$-cell death
}

\author{
Patricia Thomas ${ }^{1 *} \mathbb{C}$, Kaiyven A. Leslie ${ }^{2}$, Hannah J. Welters ${ }^{2}$ and Noel G. Morgan²
}

\begin{abstract}
Obesity is a major risk factor for type 2 diabetes (T2D) although the causal links remain unclear. A feature shared by both conditions however is systemic inflammation and raised levels of circulating fatty acids (FFA). It is widely believed that in obese individuals genetically prone to T2D, elevated levels of plasma FFA may contribute towards the death and dysfunction of insulin-producing pancreatic $\beta$-cells in a process of (gluco)lipotoxicity. In support of this, in vitro studies have shown consistently that long-chain saturated fatty acids (LC-SFA) are toxic to rodent $\beta$-cells during chronic exposure (> $24 \mathrm{~h}$ ). Conversely, shorter chain SFA and unsaturated species are well tolerated, suggesting that toxicity is dependent on carbon chain length and/or double bond configuration. Despite the wealth of evidence implicating lipotoxicity as a means of $\beta$-cell death in rodents, the evidence that a similar process occurs in humans is much less substantial. Therefore, the present study has evaluated the effects of chronic exposure to fatty acids of varying chain length and degree of saturation, on the viability of human $\beta$-cells in culture. We have also studied the effects of a combination of fatty acids and pro-inflammatory cytokines. Strikingly, we find that LC-FFA do not readily promote the demise of human $\beta$-cells and that they may even offer a measure of protection against the toxic effects of pro-inflammatory cytokines. Therefore, these findings imply that a model in which elevated circulating LC-FFA play a direct role in mediating $\beta$-cell dysfunction and death in humans, may be overly simplistic.
\end{abstract}

Keywords: Long-chain fatty acids, Human pancreatic $\beta$-cells, Pro-inflammatory cytokines, Lipotoxicity, Type 2 diabetes

\section{Background}

The process of fatty acid (FFA) induced $\beta$-cell death (frequently referred to as lipotoxicity) is often mooted as a factor mediating the reduction of functional pancreatic $\beta$-cell mass in type 2 diabetes (T2D) [1-3]. This is important because there is increasing evidence that obesity and T2D are linked very closely and it has been established that obesity is among the most important risk factors for

\footnotetext{
*Correspondence: p.thomas@bham.ac.uk

${ }^{1}$ Institute of Metabolism and Systems Research, Birmingham Medical School, University of Birmingham, Birmingham, UK

Full list of author information is available at the end of the article
}

T2D in genetically predisposed individuals [4]. Thus, it is conceived that an accumulation of abdominal adipose tissue (AT), coupled with decreased sensitivity of peripheral and hepatic tissue to the actions of insulin, causes systemic inflammation and elevated levels of FFA in the blood $[5,6]$ which are then potentially harmful to pancreatic $\beta$-cells. This hypothesis has received ample support from studies performed in vitro, where it is now indisputable evidence that incubation of rodent pancreatic $\beta$-cells with long chain saturated fatty acids leads to a loss of viability $[1,7-10]$.

The accumulation of abdominal AT associated with the onset of obesity in humans has additional 
consequences in that it is also associated with a decrease in the production of anti-inflammatory mediators (e.g. adiponectin), and an increase in the secretion of pro-inflammatory signalling molecules (e.g. IL- 6 and TNF- $\alpha$ ) by adipocytes and AT residing immune cells [5, 6]. Moreover, it has become clear by study of pancreas sections recovered at autopsy from subjects with T2D, that islet macrophage infiltration is increased compared to non-diabetic individuals [11]. Taken together, this evidence implies that obesity may be associated with the establishment of an islet milieu favouring $\beta$-cell dysfunction and loss since it is well established that pro-inflammatory cytokines can initiate apoptosis in rodent and human $\beta$-cells in vitro [7, 12-14]. Given that an expansion of AT leads to the enlargement of adipocytes and to a corresponding increase in the release of FFAs into the blood [15], and that this is associated with an abnormal rise in plasma levels of long-chain saturated fatty acid species (LCSFA), including palmitate and stearate [16-18], the islet might be considered to lie at the centre of a "perfect storm" in which $\beta$-cell demise is favoured.

This scenario may, however, represent an over-simplification of the situation since it is also well-established that not all LC-FFAs are toxic to $\beta$-cells. Indeed, a recent epidemiological study [19] has implied that higher circulating concentrations of LC-SFA having odd numbered carbon chains, such as pentadecanoic (C15:0) and heptadecanoic (C17:0) acid, may exert positive effects on $\beta$-cells. Moreover, short and medium chain SFA $(\leq \mathrm{C} 14: 0)$ are relatively inert [7] and most LC-MUFA are well tolerated by $\beta$-cells. In fact, these fatty acid species appear to exert a cytoprotective influence, by attenuating the toxic effects of palmitate when rodent $\beta$-cells are co-exposed to both agents $[2,7,8]$. Furthermore, there is little firm evidence that the progression of T2D is associated with extensive $\beta$-cell loss in human subjects and recent studies have revealed that $\beta$-cell function can be rapidly regained in response to early and dramatic weight loss [20] or after bariatric surgery in people with T2D [21]. This implies that, while $\beta$-cells may become dysfunctional in T2D, they do not die in large numbers. Thus, although the evidence linking chronic LC-FFA exposure to $\beta$-cell loss has validity for rodent cells maintained in tissue culture, it is much less clear that a similar situation obtains in humans. Therefore, in the present study, we have examined the effects of a range of LC-FFA on the viability of a human $\beta$-cell line, EndoC- $\beta \mathrm{H} 1$, in vitro. We have also studied the effects of exposure of human $\beta$-cells to a combination of LCFFA and pro-inflammatory cytokines.

\section{Materials and methods}

Cell culture and treatments

Insulin secreting rat-derived INS-1E cells [22] were cultured in RPMI-1640 containing $11 \mathrm{mmol} / \mathrm{l}$ glucose (Lonza, Basel, Switzerland) and supplemented with $100 \mathrm{U} / \mathrm{ml}$ penicillin and $100 \mu \mathrm{g} / \mathrm{ml}$ streptomycin, $2 \mathrm{mM}$ L-glutamine, 10\% foetal bovine serum (FBS) and $50 \mathrm{mmol} / \mathrm{l} 2$-mercaptoethanol (all from ThermoFisher, Boston, MA, USA). EndoC- $\beta \mathrm{H} 1$ cells (sourced from Univercell-Biosolutions) were cultured as detailed in [23], with DMEM or DMEM/F-12 Ham (50\%:50\% w/w; Merck, Darmstadt, Germany) media containing $5.5 \mathrm{mM}$ glucose and supplemented with $2 \%(\mathrm{w} / \mathrm{v})$ bovine serum albumin (BSA), $50 \mathrm{mM} \beta$-mercaptoethanol, $10 \mathrm{mM}$ Nicotinamide, $100 \mathrm{U} / \mathrm{ml}$ penicillin and $100 \mu \mathrm{g} / \mathrm{ml}$ streptomycin, $2 \mathrm{mM}$ L-glutamine, $5.5 \mu \mathrm{g} / \mathrm{ml}$ transferrin and 2.7 nM sodium selenite (sourced as described in [23]). Passage numbers did not exceed 40 and cells routinely tested negative for mycoplasma contamination. For individual experiments, cells were seeded in 12-well plates at a density of $0.5 \times 10^{6}$ cells/well and incubated for $24 \mathrm{~h}$ in complete medium. After $24 \mathrm{~h}$, the extracellular medium was removed and replaced with fresh culture medium devoid of FBS or BSA but containing the appropriate LC-FFA/BSA complexes. Where relevant, cells were incubated with proinflammatory cytokines (TNF- $\alpha$, IL1- $\beta$, IFN- $\gamma$, IL-6 (20 ng/ml) all from R\&D systems, UK).

\section{Fatty acid preparation}

LC-FFA/BSA complexes were prepared in accordance with [8]. Briefly, LC-FFA (Merck) were dissolved in ethanol and conjugated to fatty acid free BSA (Roche, Basal, Switzerland) by incubation at $37{ }^{\circ} \mathrm{C}$ for a time period of $1 \mathrm{~h}$. The final concentration of BSA was constant at $1 \%(\mathrm{w} / \mathrm{v})$ and ethanol used for cell incubations was maintained at $0.5 \%(\mathrm{v} / \mathrm{v})$. Control cells were treated with vehicle (BSA plus ethanol) only and described interchangeably as $0 \mu \mathrm{M}$ or vehicle control.

\section{Cell death analysis by flow cytometry}

Cell death was estimated on a BD Accuri ${ }^{\mathrm{TM}} \mathrm{C} 6$ Plus flow cytometer after propidium iodide (Merck; 100) staining as described previously [24]. Experiments were repeated a minimum of 3 times with $2-4$ repeats within each experiment.

\section{Data analysis}

Experimental results are expressed as mean + standard error of the mean (SEM). Statistical analysis was performed using GraphPad Prism version 8.0 (https ://www.graphpad.com/scientific-software/prism/). 
Statistical significance between mean values was calculated by one-way analysis of variance (ANOVA) with post hoc Tukey's test. The difference between groups and control was regarded as significant when $p<0.01$.

\section{Results}

Palmitate is selectively toxic to rodent but not human

$\beta$-cells

Palmitate (C16:0) is the most abundant LC-SFA in the circulation [25], and the effects of chronic exposure $(\geq 24 \mathrm{~h})$ of rodent INS-1E and human EndoC- $\beta \mathrm{H} 1$ cells to palmitate were investigated. As expected, C16:0 caused a dose-dependent loss of viability when INS$1 \mathrm{E}$ cells were treated with increasing concentrations of C16:0 for $24 \mathrm{~h}$ (Fig. 1a). Surprisingly however, over this time course, exposure to C16:0 did not cause any loss in viability of EndoC- $\beta \mathrm{H} 1$ cells. This was also true even when cells were exposed to this fatty acid at concentrations as high as $500 \mu \mathrm{M}$, over an extended exposure period of up to $72 \mathrm{~h}$ (Fig. 1b). Similarly, C16:0 [500 $\mu \mathrm{M}]$ was well tolerated by EndoC- $\beta \mathrm{H} 1$ cells even in the presence of high glucose [20 mM] (Fig. 1c) which has previously been suggested to exacerbate lipotoxicity in rodent $\beta$-cells [3].

In one recent study [26], similar results were obtained but it was proposed that the response varied according to the culture medium in which the cells were grown. Therefore, we substituted the standard growth medium for EndoC- $\beta \mathrm{H} 1$ cells, DMEM, with a second medium, DMEM/Ham's F12 mixture, since the latter has been proposed to render the cells sensitive to the toxic effects of C16:0 [26]. However, we observed no increase in EndoC- $\beta \mathrm{H} 1$ cell death when cells were treated with C16:0 $[500 \mu \mathrm{M}]$ in DMEM/Ham's F12 medium (Fig. 1d).

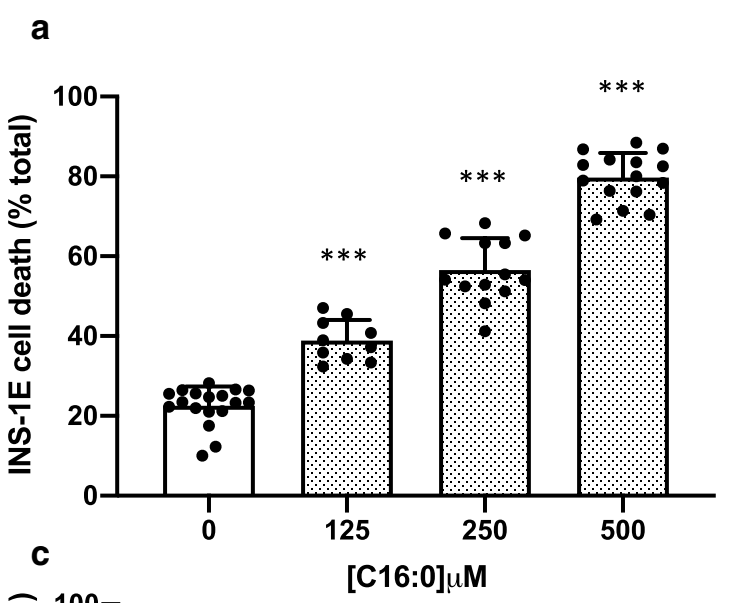

\section{b}
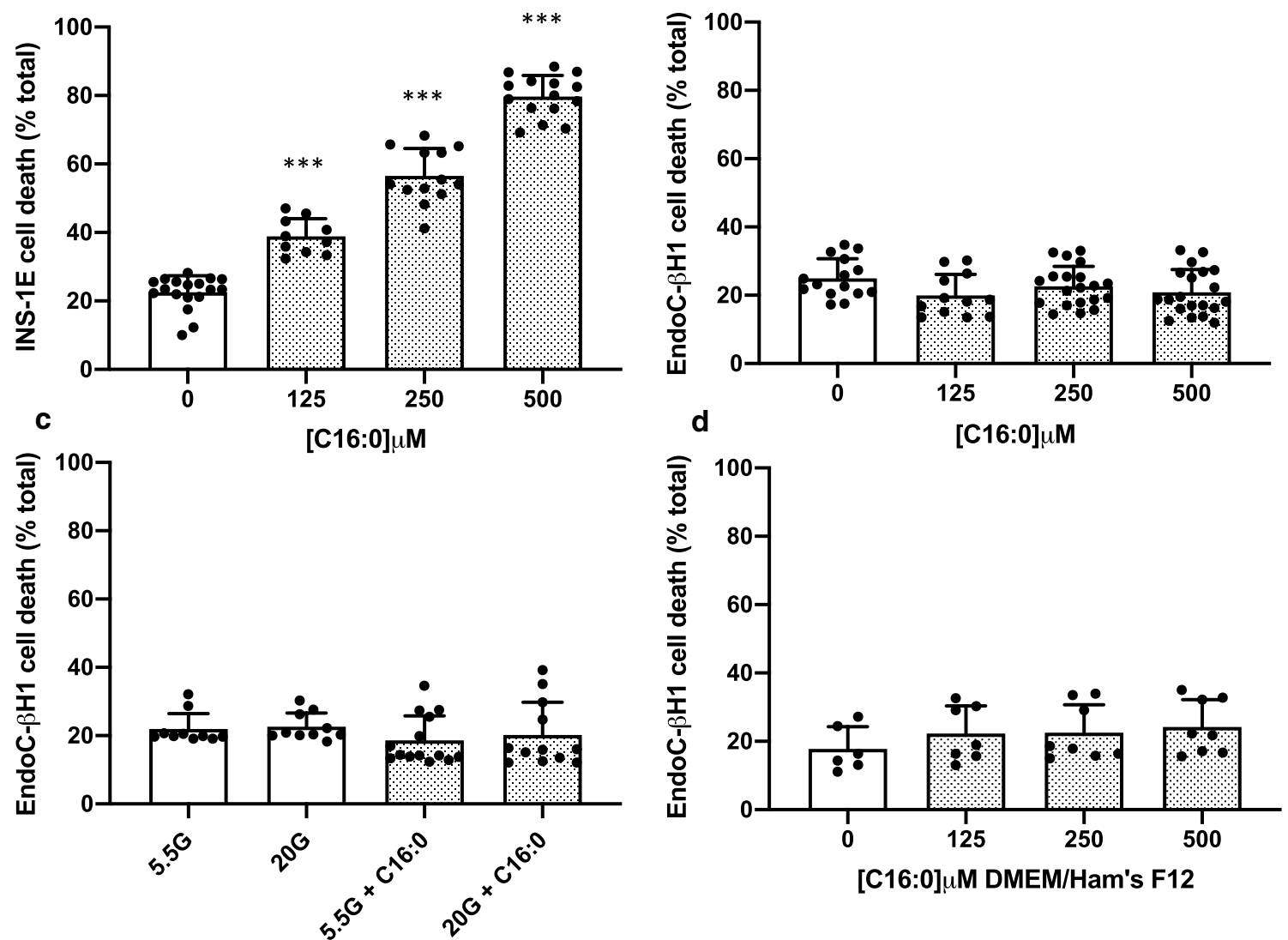

Fig. 1 The effect of the LC-SFA, palmitate, on pancreatic $\beta$-cell viability. INS-1E (a) and EndoC- $\beta \mathrm{H} 1$ (b) cells were treated with vehicle $[0 \mu \mathrm{M}], 125 \mu \mathrm{M}$, $250 \mu \mathrm{M}$ or $500 \mu \mathrm{M} \mathrm{C16:0} \mathrm{for} 24 \mathrm{~h}$ or $72 \mathrm{~h}$, respectively. EndoC- $\beta \mathrm{H} 1$ cells were exposed to $5.5 \mathrm{mM}$ or $20 \mathrm{mM}$ glucose (G) with or without $500 \mu \mathrm{M}$ C16:0 for $72 \mathrm{~h}$ (c), or incubated for $72 \mathrm{~h}$ in DMEM/Ham's F12 complete culturing medium with increasing concentrations of C16:0 [0-500 $\mu$ M] (d). Cell death was assessed using flow cytometry after staining with propidium iodide. Dots represent individual data points from a minimum of three independent experiments and the histograms represent mean values + SEM. ${ }^{* * *} p<0.001$ relative to vehicle $[0 \mu \mathrm{M}]$ 
Effects of other long-chain saturated fatty acids (LC-SFA) on the viability of rodent and human $\beta$-cells

Next, we sought to explore if fatty acid chain length was a determinant of the extent of toxicity in rat or humanderived $\beta$-cells. Exposure of INS-1E cells to $500 \mu \mathrm{M}$ of the LC-SFAs, pentadecanoic (C15:0), heptadecanoic (C17:0), stearic (C18:0) and nonadecanoic (C19:0) acid, resulted in a dramatic increase in cell death after $24 \mathrm{~h}$ (Fig. 2a). However, toxicity did not correlate directly with chain length, since, when INS-1E cells were incubated with FFAs at the very high concentration of $500 \mu \mathrm{M}, \mathrm{C} 15: 0$ caused significantly $(p=0.002)$ greater cell death than was seen with longer chain saturated species. This was also true when a lower concentration $[250 \mu \mathrm{M}]$ was employed (as shown in Additional file 1: Supplementary figure 1).
By contrast with rodent $\beta$-cells, human EndoC- $\beta \mathrm{H} 1$ cells were much less sensitive to the detrimental effects of $500 \mu \mathrm{M}$ of long chain FFAs such as C15:0, C17:0 or C18:0 (Fig. 2b) since their viability was maintained at high levels even after $72 \mathrm{~h}$ of treatment. Strikingly, exposure of the EndoC- $\beta \mathrm{H} 1$ cells to $\mathrm{C} 19: 0$ caused a marked increase $(p<0.0001)$ in death (Fig. 2b) although, even in this case, the lipotoxic effects were less potent than in INS-1E cells (compare Fig. $2 \mathrm{c}+\mathrm{d}$ ). The loss of viability of EndoC- $\beta \mathrm{H} 1$ cells required concentrations of $\geq 500 \mu \mathrm{M}$ whereas, in INS-1E cells, death was increased significantly at concentrations as low as $125 \mu \mathrm{M}$.

Long-chain monounsaturated fatty acids are well tolerated by both human and rodent $\beta$-cells

In confirmation of previous studies [7, 24], the longchain monounsaturated fatty acid (LC-MUFA), oleic acid
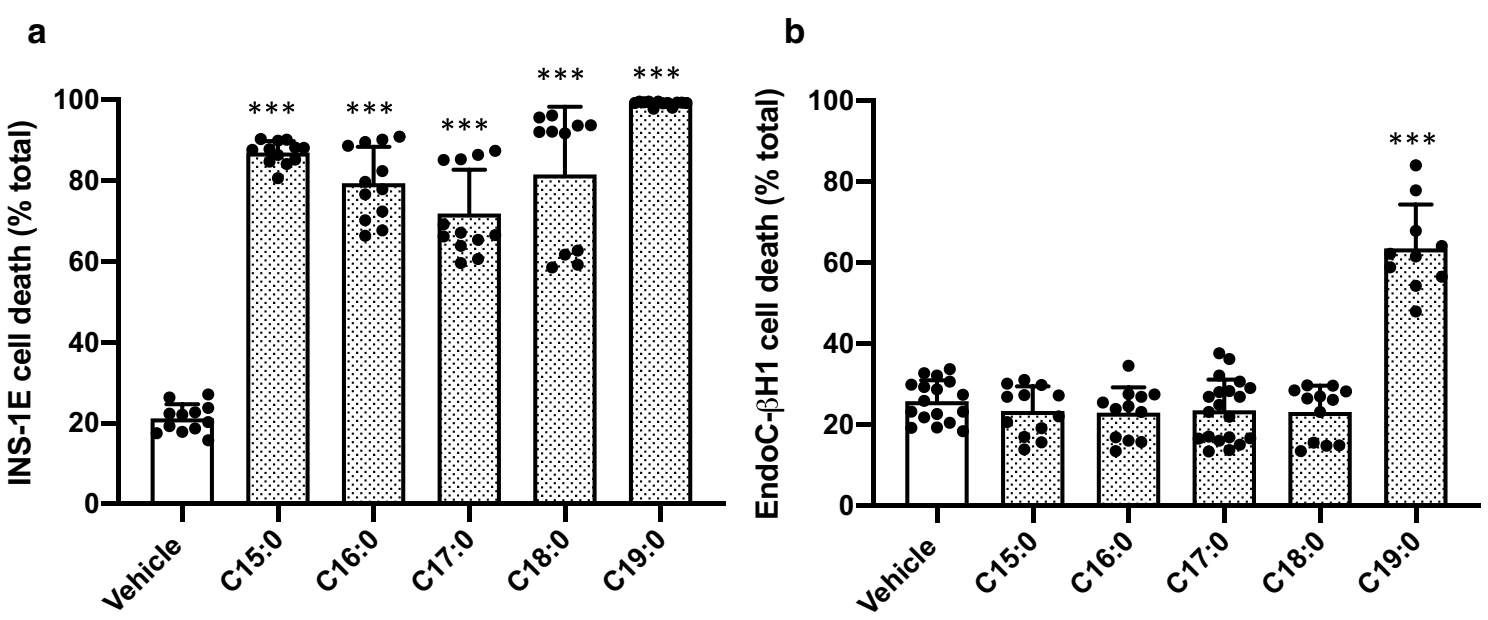

C

d
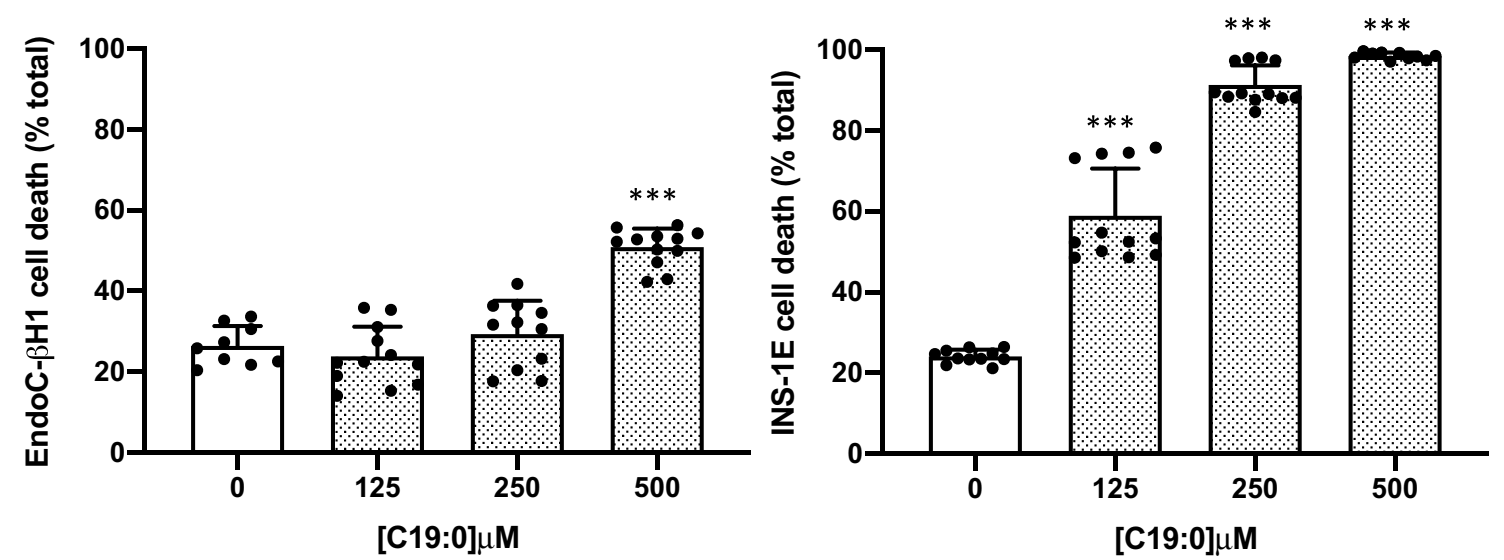

Fig. 2 The effect of LC-SFA, increasing in carbon chain length, on $\beta$-cell viability. INS-1E (a) or EndoC- $\beta \mathrm{H} 1$ (b) cells were treated with vehicle $[0 \mu \mathrm{M}]$ or $500 \mu \mathrm{M}$ of C15:0, C16:0, C17:0, C18:0 or C19:0 for $24 \mathrm{~h}$ or $72 \mathrm{~h}$, respectively. EndoC- $\beta \mathrm{H} 1$ (c) or INS-1E (d) cells were exposed to either vehicle $[0 \mu \mathrm{M}], 125 \mu \mathrm{M}, 250 \mu \mathrm{M}$ or $500 \mu \mathrm{M}$ C19:0 for $72 \mathrm{~h}$ or $24 \mathrm{~h}$, respectively. Cell death was assessed using flow cytometry after staining with propidium iodide. Dots represent individual data points from a minimum of three independent experiments and the histograms represent mean values + SEM. *** $p<0.001$ relative to vehicle $[0 \mu \mathrm{M}]$ 
(C18:1; $250 \mu \mathrm{M})$, did not promote any loss of viability in INS-1E cells. Moreover, co-incubation of these cells with C16:0 and C18:1 for 24 h led to an attenuation of the extent of cell death seen with C16:0 alone (Fig. 3a). Similar, to the situation in INS-1E cells, exposure of EndoC- $\beta \mathrm{H} 1$ cells to $\mathrm{C} 18: 1$ was not associated with any loss of viability (Fig. 3b).

\section{LC-FFAs attenuate cytokine induced $\beta$-cell death in EndoC- $\beta \mathrm{H} 1$ cells}

We, and others, have previously shown that culture in the presence of a cocktail of pro-inflammatory cytokines induces the loss of viability in rodent $\beta$-cells. Moreover, we also discovered that this response was inhibited upon inclusion of the LC-MUFAs, C16:1 or C18:1, in the incubation medium [7]. In the present work, we have confirmed that EndoC- $\beta \mathrm{H} 1$ cells also succumb to proinflammatory cytokines (Fig. 4), confirming previous reports by ourselves [7, 12] and others [13]. Surprisingly, however, we found that, when $250 \mu \mathrm{M}$ of C16:0, C16:1 or C18:1 were also present in the incubation medium, cytokine-induced cell death was attenuated significantly (although, LC-FFAs did not offer complete protection against cytokine induced death under these conditions).

\section{Discussion}

In this study we show that human $\beta$-cells are much less sensitive to the "toxic" effects of LC-FFA than rodent $\beta$-cells when exposed to FFAs in tissue culture conditions. It is well established that LC-SFA cause the rapid

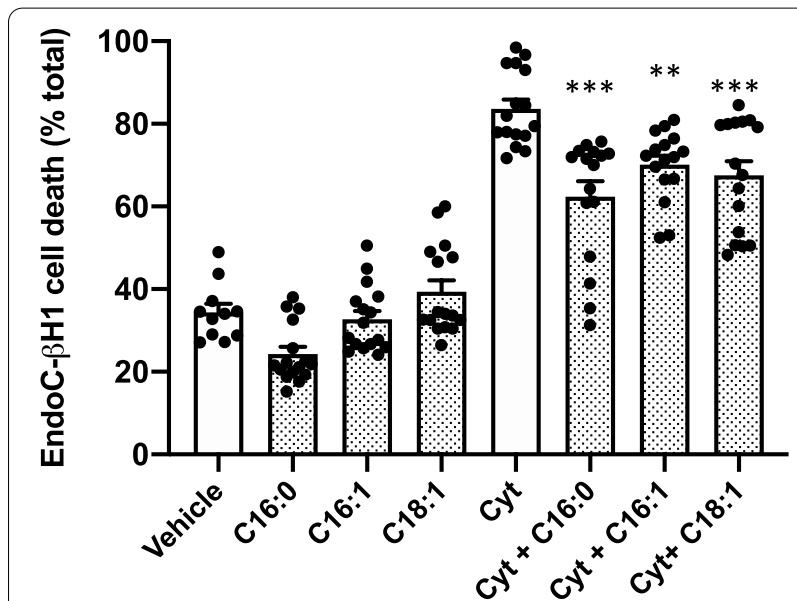

Fig.4 The effect of LC-FFA on $\beta$-cell viability when co-incubated with pro-inflammatory cytokines. EndoC- $\beta \mathrm{H} 1$ cells were exposed to vehicle $[0 \mu \mathrm{M}]$ or $250 \mu \mathrm{M} \mathrm{C16:0,C16:1} \mathrm{or} \mathrm{C18:1} \mathrm{with} \mathrm{and} \mathrm{without}$ a cytokine cocktail (cyt; 20 ng TNF- $\alpha$, IL1- $\beta$, IFN- $\gamma$, and IL-6) for $48 \mathrm{~h}$. Cell death was assessed using flow cytometry after staining with propidium iodide. Dots represent individual data points from a minimum of three independent experiments and the histograms represent mean values + SEM. ${ }^{* *} p<0.01 ;{ }^{* * *} p<0.001$ relative to cytokine [Cyt] vehicle [0 $\mu \mathrm{M}$ LC-FFA] control

demise of rodent $\beta$-cells in culture $[1,7-10]$ and we have now verified that this applies equally to FFAs having either even or odd-numbered carbon chains. Conversely, we find that LC-SFA were well tolerated by human $\beta$-cells, even when present in the culture medium at high concentrations for extended periods of time. We a

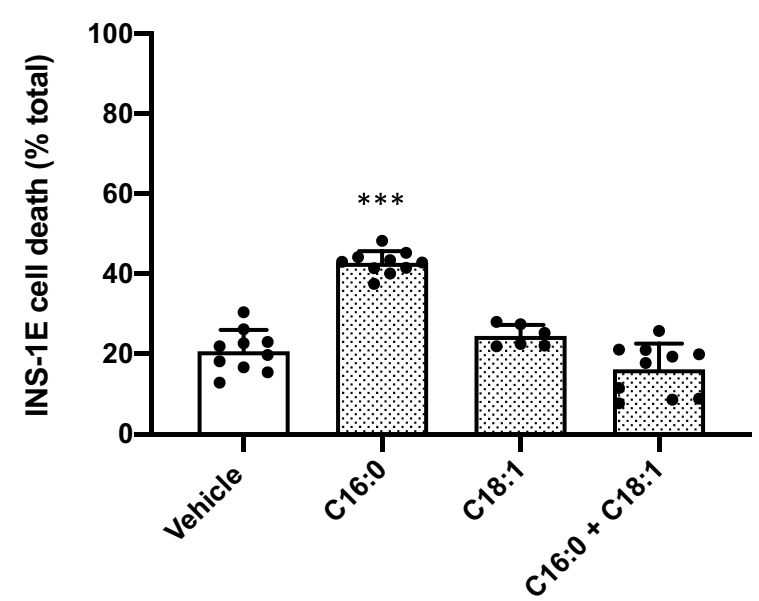

b

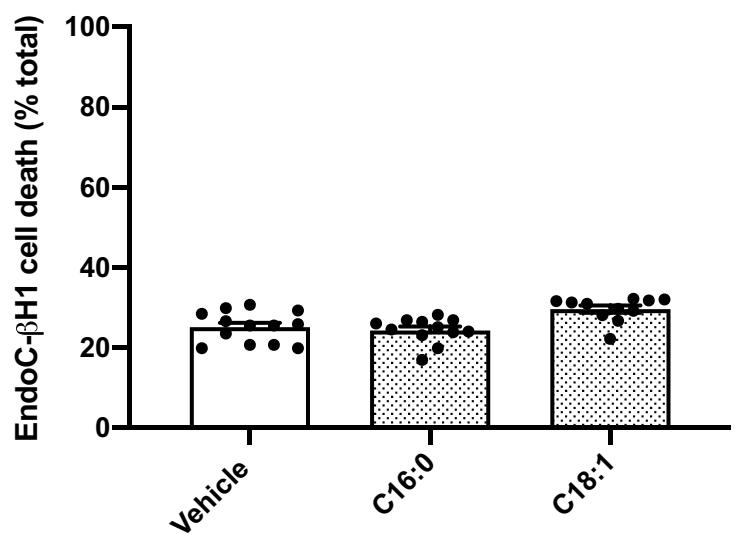

Fig. 3 The effect of long-chain monounsaturated fatty acids on $\beta$-cell viability. INS-1E (a) cells were treated with vehicle [0 $\mu \mathrm{M}]$ or $250 \mu \mathrm{M}$ C16:0, or C18:1 either alone or in combination [500 $\mu \mathrm{M}$ ] for $24 \mathrm{~h}$. EndoC- $\beta \mathrm{H} 1$ cells were exposed to vehicle [0 $\mu \mathrm{M}]$ or $500 \mu \mathrm{M}$ C16:0 or C18:1 (b) for 72 h. Cell death was assessed using flow cytometry after staining with propidium iodide. Dots represent individual data points from a minimum of three independent experiments and the histograms represent mean values $+\mathrm{SEM} .{ }^{* *} p<0.001$ relative to vehicle [0 $\left.\mu \mathrm{M}\right]$ 
did note, however, that, somewhat paradoxically, C19:0 was capable of initiating cell death when present at high concentrations. The failure of most species of LC-FFA to promote the loss of viability of human $\beta$-cells was not altered by the concomitant presence of an elevated glucose concentration $(20 \mathrm{mM})$, implying that glucose does not accentuate lipotoxicity in these cells. It was also unaffected by a change in the culture medium, which differs from the findings of others [26]. Moreover, in our hands, the LC-MUFA, C18:1, was also well tolerated by human $\beta$-cells, in contrast to another earlier report [10].

Taken together, these data imply that there are marked differences between the responses of rodent and human $\beta$-cells during chronic exposure to LC-FFA and they imply that earlier data obtained with rodent cells may require to be reconsidered before they are simply extrapolated to the human situation. This is especially true when considering circumstances (such as might be found in T2D) when islets are exposed to elevated concentrations of FFA acids in the context of a rise in pro-inflammatory cytokines. Rather than leading to an exacerbation of $\beta$-cell loss under these conditions, as might be expected, we found that cell death was attenuated. The mechanisms involved have not been disclosed and warrant further study but the data cast doubt on the likelihood that human $\beta$-cell loss is necessarily enhanced when elevations in LC-FFA are coupled with an increase in pro-inflammatory cytokines.

The findings of this study support those of earlier reports [26-28] in which EndoC- $\beta \mathrm{H} 1$ cells were shown to be resistant to C16:0 at concentrations of up to $1 \mathrm{mM}$ during exposure periods of $72 \mathrm{~h}$, both in the absence and presence of high glucose concentrations. However, they are at odds with the work of Plötz et al. who reported that $\mathrm{C} 16: 0, \mathrm{C} 18: 0, \mathrm{C} 19: 0$ and $\mathrm{C} 18: 1$ were toxic to EndoC- $\beta \mathrm{H} 1$ cells $[10,29]$. Currently, we are uncertain of the reasons for this disparity but it may reflect technical differences since the studies of Plötz et al. mainly used caspase 3 activity measurement as a surrogate for apoptosis although they also compared these with other measures of toxicity. Interestingly, Oshima and colleagues [28] also found that LC-FFAs were well tolerated by EndoC- $\beta \mathrm{H} 1$ cells and proposed that this may be due to elevated expression of the enzyme, stearoyl CoA desaturase (SCD), in a mechanism similar to that which can be achieved in rodent $\beta$-cells upon increasing the expression of SCD [30].

To the best of our knowledge, we are the first to characterise the toxicity profile of odd-chain LC-SFA, C15:0 and C17:0 in either human or rodent $\beta$-cells. We found no difference in the toxicity profile of odd-and even-chained LC-SFA, and toxicity did not increase with carbon chain length in either rodent or human $\beta$-cells. Interestingly,
C19:0 did induce EndoC- $\beta \mathrm{H} 1$ cell death, although we also noted that that $\mathrm{C} 19: 0$ was prone to precipitate in solution, and we cannot exclude that this non-specific physical property may have contributed to the response. This tendency towards precipitation was not observed to the same extent with other LC-SFA.

Our studies have revealed a further unexpected action of LC-FFA in EndoC- $\beta \mathrm{H} 1$ cells since we observed a reduction in the level of cytokine-induced cell death during co-incubation of EndoC- $\beta \mathrm{H} 1$ cells. Although, a similar phenomenon has been observed in clonal rodent $\beta$-cells exposed to IL- $1 \beta$ and IFN- $\gamma$ in the presence of LCMUFA such as C16:1 or C18:1 [7] an attenuation of cell death has not been attributed previously to the presence of LC-saturated FFA. We found that both monounsaturated and saturated LC-FFAs were cytoprotective under these conditions in EndoC- $\beta \mathrm{H} 1$ cells.

\section{Conclusion}

In summary, the results of our present investigations together with those of others [26-28] suggest that, unlike rodent $\beta$-cells, human $\beta$-cells do not readily succumb to the toxic effects of LC-FFA. Rather, under certain conditions, LC-FFA may even promote the maintenance of viability in human EndoC- $\beta \mathrm{H} 1$ cells. Future work will be required to determine whether the responses seen in EndoC- $\beta \mathrm{H} 1$ cells recapitulate those of primary human islet cells but, in principle, the present data support the doubts expressed recently by Weir [31] who has cast doubt on the concept that human $\beta$-cell loss is favoured under conditions such as those which might be encountered during obesity-induced T2D in humans.

\section{Supplementary information}

The online version contains supplementary material available at https://doi. org/10.1186/s12986-021-00541-8.

Additional file 1: Supplementary figure 1. The effect of exposing rodent $\beta$-cells to LC-SFA, increasing in carbon chain length, at a concentration of $250 \mu \mathrm{M}$ for $24 \mathrm{~h}$, on viability.

Additional file 2: Raw datasets. Raw data (Figures 1-4, sup. fig.1) on which the conclusions of the manuscript rely.

\section{Abbreviations}

AT: Adipose tissue; ANOVA: Analysis of variance; BSA: Bovine serum albumin; C15:0: Pentadecanoic acid; C16:0: Palmitic acid; C16:1: Palmitoleic acid; C17:0: Heptadecanoic acid; C18:0: Stearic acid; C18:1: Oleic acid; C19:0: Nonadecanoic acid; DMEM: Dulbecco's Modified Eagle Medium; FBS: Foetal bovine serum; IFN-y: Interferon gamma; IL-6: Interleukin-6; IL 1- $\beta$ : Interleukin-1 beta; LC-FFA: Long-chain free fatty acid; LC-MUFA: Long-chain monounsaturated fatty acid; LC-SFA: Long-chain saturated fatty acid; T2D: Type 2 diabetes; TNF-a: Tumor necrosis factor alpha.

Acknowledgements

We wish to thank Ravassard et al. [23] and Univercell-Biosolutions for the kind use of their EndoC- $\beta \mathrm{H} 1$ cell line. 


\section{Authors' contributions}

PT: data curation, data analysis, writing — original draft preparation, review and editing. KAL: data curation, data analysis, writing — review and editing. HJW: funding acquisition, project administration, conceptualisation, supervision, writing - review and editing. NGM: Funding acquisition, conceptualisation, investigation, formal analysis, methodology, supervision, writing —-review and editing. All authors read and approved the final manuscript.

\section{Funding}

This work was funded by Diabetes UK (project code: BDA:14/0005093) and the UKRI Medical Research Council (project code: MR/T003391/1).

\section{Availability of data and materials}

All data generated or analysed during this study are included in this published article [and its Additional File 2].

\section{Ethics approval and consent to participate}

Not applicable.

\section{Consent for publication}

Not applicable.

\section{Competing interests}

The authors declare that they have no competing interests.

\section{Author details}

${ }^{1}$ Institute of Metabolism and Systems Research, Birmingham Medical School, University of Birmingham, Birmingham, UK. ${ }^{2}$ Institute of Biomedical and Clinical Research, College of Medicine and Health, University of Exeter, Exeter, UK.

Received: 16 October 2020 Accepted: 4 January 2021

Published online: 12 January 2021

\section{References}

1. Oh YS, Bae GD, Baek DJ, Park EY, Jun HS. Fatty acid-induced lipotoxicity in pancreatic beta cells during development of type 2 diabetes. Front Endocrinol. 2018;9:384.

2. Maedler K, Oberholzer J, Bucher P, Spinas GA, Donath MY. Monounsaturated fatty acids prevent the deleterious effects of palmitate and high glucose on human pancreatic $\beta$-cell turnover and function. Diabetes. 2003;52:3.

3. Poitout V, Amyot J, Semache M, Zarrouki B, Hagman D, Fontes G. Glucolipotoxicity of the pancreatic $\beta$-cell. Biochim Biophys Acta. 2010;1801:3.

4. Zheng Y, Ley SH, Hu FB. Global aetiology and epidemiology of type 2 diabetes and its complications. Nat Rev Endocrinol. 2018;14:2.

5. Cao H. Adipocytokines in obesity and metabolic disease. J Endocrinol. 2014;220:2.

6. Shimobayashi M, Albert V, Woelnerhanssen B, Frei IC, Weissenberger $D$, Meyer-Gerspach AC, et al. Insulin resistance causes inflammation in adipose tissue. J Clin Investig. 2018;128:4.

7. Welters HJ, Tadayyon M, Scarpello JH, Smith SA, Morgan NG. Monounsaturated fatty acids protect against beta-cell apoptosis induced by saturated fatty acids, serum withdrawal or cytokine exposure. FEBS Lett. 2004;560:1-3.

8. Diakogiannaki E, Dhayal S, Childs CE, Calder PC, Welters HJ, Morgan NG Mechanisms involved in the cytotoxic and cytoprotective actions of saturated versus monounsaturated long-chain fatty acids in pancreatic ß-cells. J Endocrinol. 2007;194:2.

9. Hellemans KH, Hannaery JC, Denys B, Steffensen KR, Raemdonck C, Martens GA, Van Veldhoven PP, Gustafsson JA, Pipeleers D. Susceptibility of pancreatic beta cells to fatty acids is regulated by LXR/PPAR a-dependent Stearoyl-Conenzyme A desaturase. PLOS ONE. 2009;4:9.

10. Plötz T, Krummel B, Pingitore A, Persaud SJ, Elsner M, Mehmeti I, Lenzen $\mathrm{S}$. The monounsaturated fatty acid oleate is the major physiological toxic free fatty acid for human $\beta$-cells. Nutr Diabetes. 2017;7:12.

11. Richardson SJ, Willcox A, Bone AJ, Foulis AK, Morgan NG. Islet-associated macrophages in type 2 diabetes. Diabetologia. 2009;52:8.

12. Leslie KA, Russell MA, Taniguchi K, Richardson SJ, Morgan NG. The transcription factor STAT6 plays a critical role in promoting beta cell viability and is depleted in islets of individuals with type 1 diabetes. Diabetologia. 2019;62:1.

13. Gurgul-Convey E, Mehmeti I, Plotz T, Jorns A, Lenzen S. Sensitivity profile of the human EndoC- $\beta \mathrm{H} 1$ beta cell line to proinflammatory cytokines. Diabetologia. 2016;59:10.

14. Demine S, Schiavo AA, Main-Canas S, Marchetti P, Cnop M, Eizirik DL. Proinflammatory cytokines induce cell death inflammatory responses, and endoplasmic reticulum stress in human iPSC-derived beta cells. Stem Cell Res Ther. 2020;11:1.

15. Boden G. Obesity, insulin resistance and free fatty acids. Curr Opin Endocrinol Diabetes Obes. 2011;18:2.

16. Rebelos E, Seghieri M, Natali A, Balkau B, Golay A, Piatti PM, Lalic NM, Laako M, Mari A, Ferrannini E. Influence of endogenous NEFA on $\beta$-cell function in humans. Diabetologia. 2015;59:10.

17. Liu L, Li Y, Guan C, Li K, Wang C, Feng R, Sun C. Free fatty acid metabolic profile and biomarkers of isolated post-challenge diabetes and type 2 diabetes mellitus based on GC-MS and multivariate statistical analysis. J Chromatogr B Analyt Technol Biomed Life Sci. 2010;878:28.

18. Lu Y, Wang Y, Ong CN, Subramaniam T, Won Choi H, Yuan JM, Koh WP, Pan A. Metabolic signatures and risk of type 2 diabetes in a Chinese population: an untargeted metabolomic study using both LC-MS and GC-MS. Diabetologia. 2016;59:11.

19. Forouhi NG, Koulman A, Sharp SJ, Imamura F, Kröger J, Schulze MB, et al. Differences in the prospective association between individual plasma phospholipid saturated fatty acids and incident type 2 diabetes: the EPICInterAct case-cohort study. Lancet Diabetes Endocrinol. 2014;10:2.

20. Lean MEJ, Leslie WS, Barnes AC, Brosnahan N, Thom G, McCombie L, Peters C, Zhyzhneuskaya S, et al. Primary care-led weight management for remission of type 2 diabetes (DiRECT): an open-label, cluster-randomised trial. Lancet. 2017;391:10120.

21. Douros JD, Tong J, D'Alessio DA. The effects of bariatric surgery on islet function, insulin secretion, and glucose control. Endocr Rev. 2019;40:5.

22. Asfari M, Janjic D, Meda P, Li G, Halban PA, Wollheim CB. Establishment of 2-mercaptoethanol-dependent differentiated insulin-secreting cell lines. Endocrinology. 1992;130:1.

23. Ravassard P, Hazhouz Y, Pechberty S, Bricout-Neveu E, Armanet M, Czernichow P, Scharfmann R. A genetically engineered human pancreatic $\beta$ cell line exhibiting glucose-inducible insulin secretion. J Clin Investig. 2011;121:9.

24. Dhayal S, Morgan NG. Pharmacological characterisation of the cytoprotective effects of polyunsaturated fatty acids in insulin-secreting BRINBD11 cells. Br J Pharmacol. 2011;162:6.

25. Carta G, Murru E, Banni S, Manca C. Palmitic acid: physiological role, metabolism and nutritional implications. Front Physiol. 2017;8:902.

26. Krizhanovskii C, Kristinsson H, Elksnis A, Wang X, Gavali H, Bergsten P. EndoC- $\beta \mathrm{H} 1$ cells display increased sensitivity to sodium palmitate when cultured in DMEM/F12 medium. Islets. 2017;9:3.

27. Tsonkova VG, Sand FW, Wolf XA, Grunnet LG, Ringgaard AK, Ingvorsen $C$, et al. The EndoC- $\beta \mathrm{H} 1$ cell line is a valid model of human $\beta$-cells and applicable for screenings to identify novel drug target candidates. Mol Metab. 2018. https://doi.org/10.1016/j.molmet.2017.12.007.

28. Oshima M, Pechberty S, Bellini L, Göpel SO, Campana M, Rouch C, et al. Stearoyl CoA desaturase is a gatekeeper that protects human $\beta$-cell $s$ against lipotoxicity and maintains their identity. Diabetologia. 2019;63:2.

29. Plötz T, von Hanstein AS, Krümmel B, Laporte A, Mehmeti I, Lenzen S. Structure-toxicity relationships of saturated and unsaturated free fatty acids for elucidating the lipotoxic effects in human EndoC- $\beta \mathrm{H} 1$ beta-cells. Biochim Biophys Acta Mol Basis Dis. 2019;1865:11.

30. Busch AK, Gurisik E, Cordery DV, Sudlow M, Denyer GS, Laybutt DR, Hughes WE, Biden TJ. Increased fatty acid desaturation and enhanced expression of stearoyl coenzyme A desaturase protects pancreatic beta cells from lipoapoptosis. Diabetes. 2005;54:10.

31. Weir GC. Glucolipotoxicity, beta cells, and diabetes: the emperor has no clothes. Diabetes. 2019:69:3.

\section{Publisher's Note}

Springer Nature remains neutral with regard to jurisdictional claims in published maps and institutional affiliations. 